\title{
Perbandingan Penggunaan Dua Jenis Ransum Terhadap Pertambahan Bobot Badan Harian (PBBH), Konsumsi Ransum dan Konversi Ransum Ayam Broiler
}

\author{
Aristo Kurniawan Sio ${ }^{\mathrm{a}}$, Oktovianus R. Nahak T. B ${ }^{\mathrm{b}}$, Agustinus Agung Dethan ${ }^{\mathrm{c}}$ \\ ${ }^{a}$ Fakultas Pertanian, Universitas Timor, Kefamenanu, TTU - NTT, 85613, Indonesia. \\ ${ }^{b}$ Fakultas Pertanian, Universitas Timor, Kefamenanu, TTU - NTT, 85613, Indonesia. \\ ${ }^{c}$ Fakultas Pertanian, Universitas Timor, Kefamenanu, TTU - NTT, 85613, Indonesia.
}

\section{Article Info}

\section{Article history:}

Received 14 Juni 2015

Received in revised form 12 Juli 2015

Accepted 5 Oktober 2015

\section{Keywords:}

Ransum Buatan

Ransum Konvensional

Ayam Broiler

\section{Abstrak}

Penelitian ini bertujuan membandingkan kualitas ransum yang dibuat sendiri dengan ransum konvensional terhadap penampilan (PBBH), konsumsi ransum, dan konversi ransum ayam broiler, dilaksanakan di kandang peternakan, Fakultas Pertanian Universitas Timor, Kabupaten Timor Tengah Utara selama 1 (satu) bulan lebih berlangsung dari tanggal 17 Februari sampai dengan 24 Maret 2015. Masingmasing ransum di berikan pada ayam Broiler dari umur 0-35 hari atau 5 minggu dengan melihat penampilan ayam broiler dan PBBH. Jumlah ayam broiler yang digunakan sebanyak 80 ekor. Hasil penelitian menunjukkan perlakuan ransum buatan memberikan pengaruh yang lebih baik terhadap pertambahan bobot badan, konsumsi dan konversi ransum. Bobot badan akhir umur 35 hari pada perlakuan ransum buatan dengan rataan pada kisaran 184,58-223,15 gram/ekor; dengan rata- rata akhir 205,39 gram/ekor lebih tinggi dibandingkan pada perlakuan ransum konvensional yang menghasilkan kisaran rataan 181,88-209,91 gram/ekor; dengan rata-rata 194,62 gram/ekor. Konsumsi ransum selama 35 hari pada perlakuan ransum buatan pada kisaran rataan 629,39-658,78 gram/ekor, dengan rata-rata 640,43 gram/ekor, lebih rendah dibandingkan pada perlakuan ransum konvensional yang menghasilkan rataan 695,15-728,48, dengan rata-rata 713,81 gram/ekor. Konversi ransum pada perlakuan ransum buatan berada pada kisaran ratan 2,81-3,48 gram/ekor, dengan rata- rata konversi ransum 3,12 gram, lebih baik dibandingkan pada perlakuan ransum konvensional yang menghasilkan kisaraan rataan 3,08-3,88 gram/ekor, dengan rata-rata konversi 3,67 gram. @2016 dipubikasikan oleh JAS

\section{Pendahuluan}

Perkembangan peternakan ayam broiler di Kabupaten TTU saat ini mengalami kemajuan yang sangat pesat. Perkembangan tersebut dikarenakan semakin meningkatnya kebutuhan masyarakat akan daging sebagai salah satu sumber protein.

Broiler adalah ayam ras yang sengaja dibibitkan dan dikembangkan untuk menghasilkan daging yang cepat, dibandingkan dengan daging unggas lainnya Pertumbuhan broiler yang cepat karena ransum yang disediakan tersedia zat-zat makanan yang diperlukan. Kinerja broiler dipengaruhi oleh konsumsi ransum, pertambahan berat badan, dan konversi ransum.

Adapun faktor yang berpengaruh dalam menentukan tingkat keberhasilan $\mathrm{d}$ dalam usaha peternakan ayam broiler adalah pemilihan bibit, pemberian ransum, dan manajemen pemeliharaan. Ransum merupakan faktor yang paling dominan, karena biaya yang dikeluarkan untuk ransum bisa mencapai $70 \%$ dari total biaya produksi. Ransum yang baik adalah ransum yang memenuhi kebutuhan nutrisi ternak sesuai dengan fase fisiologis serta tidak menggangu kesehatan ternak. Ransum merupakan campuran dari berbagai macam bahan pakan yang diberikan pada ternak untuk memenuhi kebutuhan nutrien selama 24 jam. Nutrien tersebut diperlukan untuk pokok, pertumbuhan, perkembangan, dan reproduksi ternak

Ransum adalah pakan jadi yang siap diberikan kepada ternak yang disusun dari berbagai jenis bahan pakan yang sudah dihitung (dikalkulasikan) berdasarkan kebutuhannya. Berdasarkan bentuknya ransum dibagi menjadi 3 jenis yaitu mash, crumble, dan pellet (Anonimous, 2008).

Ayam broiler termasuk ternak yang mempunyai tingkat koefisiensi yang tinggi dalam mengkonversi pakan menjadi daging. Dewasa ini para peternak ayam broiler masih menggunakan ransum konvensional yang dibeli dengan harga yang cukup mahal namun kualitas nutrisi yang tdk efisien sehingga memberikan dampak negatif bagi para peternak. Alhasil peternak sering mengalami keterlambatan produksi sehingga membawa pada kerugian ekonomi.

Penggunaan bahan pakan lokal seperti tepung putak (Corypha gebanga), dedak padi, tepung ikan, bungkil kedelai dan ditambah dengan bahan pakan pendukung lainnya menjadi bahan dasar lokal yang diolah menjadi ransum diharapkan membawa dampak yang positif terhadap peningkatan bobot badan ayam broiler. Campuran bahan pakan lokal diharapkan dapat mengubah penampilan ayam broiler.

Tujuan dari penelitian ini adalah untuk membandingkan kualitas ransum yang dibuat sendiri dengan ransum konvensional terhadap penampilan (PBBH ), konsumsi ransum, dan konversi ransum ayam broiler.

\section{Metode}

2.1 Waktu dan tempat penelitian

Penelitian ini telah dilaksanakan pada kandang Unggas milik Program Studi Peternakan, Fakultas Pertanian, Universitas Timor. Penelitian ini berlangsung selama 35 hari dan dimulai pada tanggal 17 Februari sampai pada tanggal 24 Maret 2015

\subsection{Materi Penelitian}

Peralatan yang digunakan adalah alat pencetakan ransum berbentuk crumble dan pellet, kandang terdiri dari dua puluh petak dan tiap petak berukuran $1 \mathrm{~m} \mathrm{x}$ $0,5 \mathrm{~m}$, tinggi dinding kandang $50 \mathrm{~cm}$ dan tinggi lantai $20 \mathrm{~cm}$, tiap petak masingmasing dilengkapi dengan tempat makan dan minum, balon pijar 100 watt serta peralatan lain timbangan, oven, gilingan sampel, baskom, plastik, terpal, peralatan tulis (buku dan ballpoint).
Bahan yang digunakan dalam penelitian ini terdiri ransum konvensional yaitu BR1 untuk ternak pada fase starter dan BR2 untuk ternak pada fase finisher Pada ransum yang dibuat menggunakan bahan berupa tepung putak, tepung ikan, dedak padi, bungkil kedelai, molases dan premix dan minyak kelapa. Vaksin yang akan digunakan terdiri dari 2 jenis vaksin yaitu ND Lasota dan ND IB.

Ternak yang dipakai dalam penelitian ini adalah day old chick (DOC) strain CP 707 produksi PT. Charoen Phockpan sebanyak 100 ekor. Bibit ayam broiler dibeli pada poultry shop yang ada di kota Kefamenanu.

Ransum ayam broiler terbagi menjadi dua jenis yaitu ransum untuk periode starter dan ransum untuk periode finisher (Murtidjo, 1991). Dalam penelitian ini digunakan 2 jenis ransum yaitu ransum buatan dengan menggunakan bahan pakan lokal dan ransum konvensional yang dibeli pada poultry shop terdekat. Kebutuhan nutrisi pakan ayam broiler dapat dilihat pada Tabel 1.

Tabel 1. Kebutuhan Nutrisi Pakan Ayam Broiler pada Periode Starter dan Periode Finisher.

\begin{tabular}{clcc}
\hline No & \multicolumn{1}{c}{ Nutrisi } & Periode Starter & Periode Finisher \\
\hline 1 & Protein ( \% ) & $23,00 \%$ & $20,00 \%$ \\
2 & Energi metabolis ( kkal / kg ) & $2800-3200$ & $2900-3200$ \\
3 & Kalsium ( \% ) & 1,00 & 0,90 \\
4 & Fosfor ( \% ) & 0,45 & 0,35 \\
\hline
\end{tabular}

Sumber: NRC (1994)

\subsection{Metode penelitian}

Data yang diambil dalam penelitian ini adalah data primer berupa data yang diperoleh dari pengamatan langsung yang dilakukan dengan menguji ransum buatan sendiri dan buatan pabrik dan data sekunder yang diperoleh dari sumbersumber yang berhubungan dengan penelitian. Pengujian kualitas ransum akan diuji dan masing-masing ransum akan di berikan pada ayam broiler dari umur 0 31 hari atau 4 minggu lamanya dengan melihat penampilan ayam broile pertambahan bobot badan harian $(\mathrm{PBBH})$ dan jumlah ayam broiler yang dipakai berjumlah 80 ekor.

\subsection{Prosedur Penelitian}

Pencampuran ransum adalah proses dimana semua bahan di campur menjadi satu kemudian bahan diaduk didalam mesin mixer untuk mendapatkan hasil yang merata. Hal ini dilakukan untuk mendapatkan hasil yang maksimal pada komposisi ransum yang dicetak. Untuk mendapatkan $100 \mathrm{~kg}$ ransum, bahan pakan yang di persiapkan seperti pada Tabel 2

Tabel 2. Bahan Pakan yang Dipersiapkan

\begin{tabular}{clc}
\hline No & \multicolumn{1}{c}{ Bahan Pakan } & Bobot $(\mathrm{kg})$ \\
\hline 1 & Tepung putak & 50 \\
2 & Dedak Padi & 10 \\
3 & Tepung ikan & 15 \\
4 & Bungkil kedelai & 17,5 \\
5 & Tepung daun papaya & 5 \\
6 & Probiotik & 0,5 \\
7 & Minyak kelapa & 1 \\
8 & Molases & 1 \\
\hline
\end{tabular}

Bahan pakan yang telah dimixer (campur) kemudian di cetak dengan menggunakan mesin pelleting untuk mendapatkan bentuk ransum. Bendasarkan jenisnya, ransum dicetak dalam 2 bentuk yaitu ransum berbentuk tepung (ransum dalam bentuk tepung diberikan pada masa starter. Hal ini dikarenakan bentuk dan 
ukuran paruh yang masih kecil) dan ransum berbentuk pellet (ransum yang di cetak berbentuk seperti tabung kecil setelah melalui pelleting yang berukuran 5 $-8 \mathrm{~mm}$. bentuk pellet ini diberikan pada ayam broiler umur dewasa dikarenakan paruh ayam yang cukup besar). Proses penggeringan dengan menggunakan oven dengan suhu $50^{\circ} \mathrm{C}$ dengan durasi waktu $2-3$ jam.

DOC yang dipakai dalam penelitian ini adalah strain CP 707 sebanyak 80 ekor yang dibeli pada toko penyedia DOC. Kandang di persiapkan dan dibuat blok dengan masing masing blok terdiri dari 10 petak, ransum konvensional disiapkan baik dalam masa statter maupun masa finisher untuk perbandingan.

\subsection{Variabel Penelitian}

Variabel yang diamati dalam penelitian ini adalah a) Pertambahan bera badan yaitu selisih antara berat badan akhir dengan berat badan awal dibagi total hari penelitian (gram/ekor/hari); b) Konsumsi ransum yaitu selisih antara jumlah pakan yang diberikan dan sisa pakan yang tidak dimakan dibagi total hari penelitian (gram/ekor/ hari); c) Konversi pakan yaitu jumlah pakan yang dikonsumsi dibagi pertambahan berat badan.

\subsection{Analisis Data}

Data dianalisa menggunakan analisis deksriptif yaitu menghitung nilai ratarata dari masing masing variabel, standar deviasi dan koefisien keragaman dengan formulasi masing masing (Sugiyono, 2006). Sementara itu untuk membandingkan produktifitas ransum yang dibuat sendiri dengan ransum konvensional digunakan uji t (t-test) berdasarkan petunjuk Soemantri dan Muhidin (2006)

\section{Hasil dan Pembahasan}

\subsection{Gambaran Umum Penelitian}

Langkah awal yang dilakukan penulis dalam penelitian ini adalah persiapan kandang yakni pembuatan kandang yang terdiri dari 20 petak kandang penelitian, yang masing - masing terdiri dari 10 petak kandang perlakuan yang menggunakan ransum konvensional dan 10 petak yang menggunakan ransum buatan, Setiap petak berukuran 1 x $0,5 \mathrm{~m}$ dan tinggi $80 \mathrm{~cm}$. pada setiap petak terdiri 4 ekor broiler, satu buah tempat makan dan minum. Pemanasan menggunakan lampu 100 watt yang diberikan satu buah untuk dua petak kandang perlakuan.

Pada saat broiler tiba dikandang penelitian, broiler langsung dibagi 40 ekor untuk perlakuan ransum konvensional dan 40 ekor untuk perlakuan ransum buatan yang kemudian ditimbang satu persatu untuk mendapatkan berat awal. Selanjutnya broiler diberi air gula untuk mencegah dehidrasi selama \pm 60 menit dan kemudian baru diberi neubro.

Hari pertama sampai hari ketiga broiler sengaja dikumpulkan baik itu pada perlakuan ransum konvensional maupun buatan agar broiler beradaptasi dengan suhu lingkungan dan makanan. Selama broiler dikumpulkan tidak ada hambatan yang terlihat baik itu stress dan penyakit. Pada hari keempat broiler divaksinasi menggunakan vaksin ND lasota (tetes mata) dipisahkan ke kandang perlakuan. Vaksinasi dilanjutkan pada umur broiler 21 hari dengan menggunakan vaksin ND IB melalui penyemprotan diatas kepala.

Pakan yang diberikan pada minggu pertama 400 gram / blok/ hari baik itu pada perlakuan ransum konvensional maupun perlakuan ransum buatan, selanjutnya pada minggu kedua diberikan 700 gram/blok/hari,minggu ketiga 800 gram/ekor/hari, dan minggu keempat sampai minggu kelima diberikan 1000 gram/blok/ hari.

Adaptasi broiler terhadap ransum yang diberikan pada perlakuan ransum buatan terlihat nampak lebih sehat dibandingkan dengan broiler pada perlakuan ransum konvensional, hal ini ditandai dengan prilaku broiler. Penimbangan broiler dilakukan setiap minggu untuk didata pertambahan bobot badan broiler.

Selama penelitian suhu lingkungan yang tidak stabil (panas dan hujan) mengakibatkan suhu lingkungan yang teratur, namun dengan demikian pertumbuhan dan perkembangan broiler selama penelitian cukup baik.

\subsection{Pertambahan Bobot Badan Broile}

Pertambahan bobot badan adalah selisih antara berat badan akhir dengan berat badan awal dibagi lama waktu penelitian (gram/ekor/hari). Pengaruh perlakuan jenis pakan yang berbeda yaitu ransum konvensional (pakan pabrik) dan pakan buatan terhadap rata - rata pertambahan berat badan broiler terlihat pada Tabel 3.

Tabel 3. Rata-Rata Pertambahan Bobot Badan (gram/ekor/hari)

\begin{tabular}{cccc}
\hline \multicolumn{2}{c}{ Ransum Buatan } & \multicolumn{2}{c}{ Ransum Konvensional } \\
\hline Blok & Rataan & Blok & Rataan \\
\hline 1 & 223,51 & 1 & 202,01 \\
2 & 200,32 & 2 & 194,01 \\
3 & 184,58 & 3 & 209,91 \\
4 & 198,56 & 4 & 197,25 \\
5 & 215,86 & 5 & 195,3 \\
6 & 196,95 & 6 & 199,58 \\
7 & 197,95 & 7 & 190,45 \\
8 & 215,73 & 8 & 193,28 \\
9 & 207,61 & 9 & 182,78 \\
10 & 212,87 & 10 & 181,88 \\
\hline Jumlah & 2053,94 & Jumlah & 1946,28 \\
\hline Rataan & 205,39 & Rataan & 194,63 \\
\hline
\end{tabular}

Pada Tabel 3. terlihat bahwa rata - rata pertambahan berat badan broiler yang mengkonsumsi ransum buatan adalah 205,394 gram/ekor/hari lebih tinggi dibandingkan dengan broiler yang mengkonsumsi ransum konvensional yaitu 194,628 gram/ekor/hari. Rata - rata perlakuan ransum buatan lebih tinggi karena pertambahan bobot badan pada setiap blok lebih tinggi dibandingkan dengan setiap blok pada ransum buatan, hal ini terlihat pada blok 1 dan blok 10 pada perlakuan ransum buatan yang mempunyai rata - rata tertinggi.

Hasil analisis (Uji-t) menunjukan bahwa perbedaan pertambahan berat badan antara kedua perlakuan ini signifikan hasil perhitungan uji t (t-test) adalah $2,24>2.101$. Perbedaan konsumsi memberikan pengaruh yang berbeda terhadap pertambahan berat badan broiler. Dengan demikian antara pakan buatan dan pakan pabrik memberikan efek yang berbeda terhadap pertambahan berat badan. Pakan buatan yang bersumber dari bahan pakan lokal dinilai lebih baik dengan ransum konvensional. Kandungan protein dan energi pada pakan buatan cukup untuk pertumbuhan broiler dari masa starter sampai finisher.

Menurut Anggorodi (1980) menyatakan Kecepatan pertumbuhan mempunyai variasi yang cukup besar, keadaan ini bergantung pada tipe ayam, jenis kelamin, galur, tata laksana, temperatur lingkungan, tempat ayam tersebut dipelihara serta kualitas, dan kuantitas makanan.

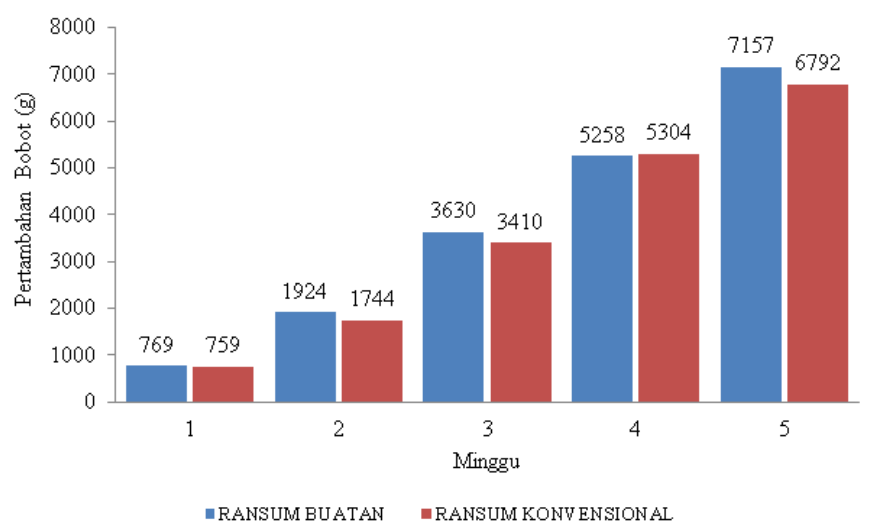

Gambar 1. Pertambahan Bobot Mingguan (g)

Gambar 1. menunjukan angka pertambahan bobot badan mingguan dari minggu pertama sampai minggu kelima. Pada minggu pertama laju pertumbuhan antara ransum buatan dan ransum konvensional hampir relative sama akan tetapi ransum buatan masih relative tinggi dengan menunjukan angka 769 gram/minggu. Minggu kedua laju pertambahan bobot badan pada perlakuan ransum buatan meningkat dengan pesat dengan mencapai angka 1924 gram/minggu dari total setiap perlakuan, begitu pun pada minggu ketiga. Pada minggu keempat laju pertambahan bobot badan pada perlakuan ransum buatan sedikit menurun kemungkinan dikarenakan keadaan cuaca daya konsumsi ransum tidak maksimal tetapi meningkat pada akhir penelitian yaitu minggu kelima dengan total pertambahan bobot badan pada perlakuan ransum buatan yaitu 7157 gram/minggu nya.

Dari Gambar 1. tersebut dapat disimpulkan bahwa ransum buatan relatif lebih baik dalam hal pertambahan bobot badan.

\subsection{Konsumsi Ransum Broiler}

Konsumsi ransum adalah selisih antara jumlah pakan yang diberikan dan sisa pakan yang tidak di makan dibagi total lama penelitian (gram/ekor/hari). Pengaruh perlakuan perbedaan jenis ransum yang berbeda yaitu ransum konvensional dan ransum buatan terhadap konsumsi ransum broiler terlihat pada Tabel 4.

Tabel 4. Rata-Rata Konsumsi Ransum (gram/ekor/hari)

\begin{tabular}{cccc}
\hline \multicolumn{2}{c}{ Ransum Buatan } & \multicolumn{2}{c}{ Ransum Konvensional } \\
\hline Blok & Rataan & Blok & Rataan \\
\hline 1 & 629,39 & 1 & 695,45 \\
2 & 658,78 & 2 & 708,78 \\
3 & 642,42 & 3 & 722,12 \\
4 & 637,87 & 4 & 709,39 \\
5 & 648,48 & 5 & 742,72 \\
6 & 635,15 & 6 & 695,15 \\
7 & 641,21 & 7 & 722,42 \\
8 & 640,40 & 8 & 728,48 \\
9 & 635,75 & 9 & 707,87 \\
10 & 636,66 & 10 & 705,75 \\
\hline Jumlah & 6406,31 & Jumlah & 7138,13 \\
\hline Rataan & 640,63 & Rataan & 713,81 \\
\hline
\end{tabular}

Pada Tabel 4. Terlihat rata- rata konsumsi ransum Nampak terlihat jelas bahwa presentasi konsumsi tertinggi pada level ransum konvensional yang mencapai angka 713,813 gram/ekor/hari dibandingkan dengan pakan buatan yang hanya mencapai angka 640,631 gram/ekor/hari. Hal ini disebabkan Kandungan energi metabolisme yang tinggi pada pakan buatan yang bersumber dari tepung sagu dan protein yang bersumber dari tepung ikan mencukupi asupan 
nutrisi pada broiler sehingga konsumsi ransum tidak meningkat pada perlakuan ransum buatan.

Hasil analisis (uji-t) menunjukan perbedaan yang tidak signifikan antara kedua ransum tersebut terhadap konsumsi ransum broiler selama penelitian. Hasil perhitungan uji t (t-test) adalah - 10,32 tidak signifikan dengan melihat pada nilai stadarisasi $t_{\text {tabel }}$ dengan nilai $2,101(-10,32<2,101)$. Perbedaan konsumsi ransum ini diduga sebagai akibat dari perbedaan kandungan nutrisi seperti kandungan protein dan kandungan energi metabolisme (EM) pada ransum tersebut. perbedaan kandungan protein ini menyebabkan broiler akan mengkonsumsi ransum yang lebih banyak jika kebutuhan energinya belum tercukupi untuk maintenance, metabolisme, produksi, dan lain - lain (Suprijatna dkk, 2005) . kebutuhan energi dari bahan karbohidrat dalam tubuh jika belum terpenuhi maka ayam akan menggunakan energi dari bahan lemak ataupun protein yang menyebabkan konsumsi ransum menjadi lebih tinggi jika didalam ransum kandungan energinya rendah.

Pakan buatan yang terdiri dari bahan pakan lokal memiliki keunggulan dalam komposisi nutrisi dikarenakan ransum buatan memakai tepung ikan sebagai sumber protein dan tepung putak sebagai sumber energi metabolisme. Menurut Sidadolog (1999) ayam akan berhenti mengkonsumsi ransum jika kebutuhan energi telah terpenuhi. Sekalipun pakan didalam temboloknya kosong namun energi di dalam tubuh telah terpenuhi maka ayam akan berhenti mengkonsumsi ransum.

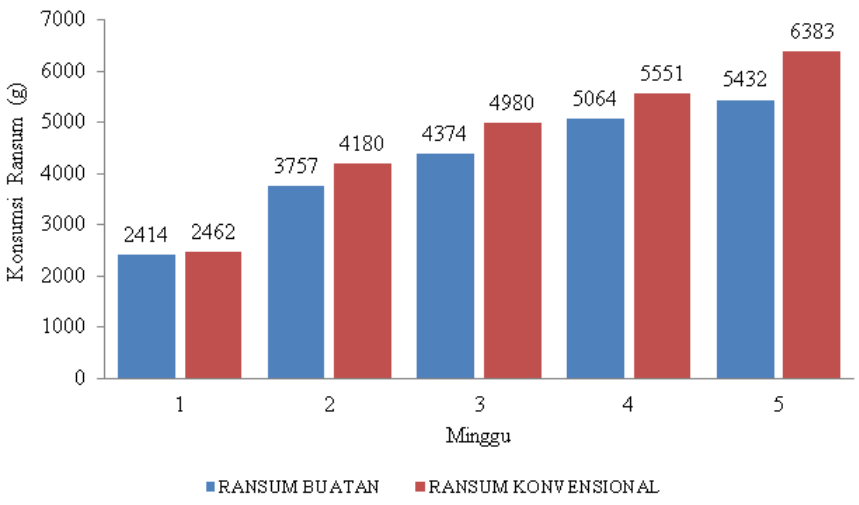

Gambar 2. Konsumsi Ransum Mingguan (g)

Gambar 2. menunjukkan konsumsi ransum pada minggu pertama menunjukan tingkat konsumsi ransum yang hampir relatif sama baik itu pada perlakuan ransum buatan maupun perlakuan ransum konvensional hal ini dikarenakan kebutuhan ransum pada masa pertumbuhan yang tinggi mengakibatkan daya konsumsi meningkat. Tetapi pada minggu kedua konsumsi ransum pada perlakuan ransum buatan mulai daya konsumsi menurun dibandingkan dengan perlakuan ransum konvensional hal ini mungkin disebabkan kebutuhan akan nutrisi sudah mulai tercukupi sehingga daya konsumsi mulai menurun. Begitupun pada minggu ketiga sampai kelima.

\subsection{Konversi Ransum Broiler}

Konversi ransum (Ration Convertion) adalah perbandingan jumlah konsumsi ransum pada satu minggu dengan pertambahan bobot badan yang dicapai pada minggu itu, bila rasio kecil berarti pertambahan bobot badan ayam memuaskan atau ayam makan dengan efisien. Hal ini dipengaruhi oleh besar badan dan bangsa ayam, tahap produksi, kadar energi dalam ransum, dan temperatur lingkungan (Rasyaf, 2004).

Nilai suatu ransum selain ditentukan oleh nilai konsumsi ransum dan tingkat pertumbuhan bobot badan juga ditentukan oleh tingkat konversi ransum, dimana konversi ransum menggambarkan banyaknya jumlah ransum yang digunakan untuk pertumbuhannya (Wiradisastra, 1986). Semakin rendah angka konversi ransum berarti kualitas ransum semaikin baik. Pengaruh perlakuan perbedaan jenis ransum yang berbeda yaitu ransum konvensional dan ransum buatan terhadap konversi ransum broiler terlihat pada Tabel 5 .

Tabel 5. Konversi Ransum Selama Penelitian

\begin{tabular}{cccc}
\hline \multicolumn{2}{c}{ Ransum Buatan } & \multicolumn{2}{c}{ Ransum Konvensional } \\
\hline Blok & Rataan & Blok & Rataan \\
\hline 1 & 2,81 & 1 & 3,44 \\
2 & 3,28 & 2 & 3,65 \\
3 & 3,48 & 3 & 3,44 \\
4 & 3,21 & 4 & 3,59 \\
5 & 3,00 & 5 & 3,80 \\
6 & 3,22 & 6 & 3,48 \\
7 & 3,23 & 7 & 3,79 \\
8 & 2,96 & 8 & 3,76 \\
9 & 3,06 & 9 & 3,87 \\
10 & 2,99 & 10 & 3,88 \\
\hline Jumlah & 31,24 & Jumlah & 36,70 \\
\hline Rataan & 3,12 & Rataan & 3,67 \\
\hline
\end{tabular}

Pada Tabel 5. terlihat bahwa angka konversi ransum broiler yang mengkonsumsi ransum konvensional adalah 3.67 lebih tinggi dibanding broiler yang mengkonsumsi ransum buatan yaitu 3.12. hal ini terlihat jelas pada konsumsi ransum dan pertambahan berat badan setiap perlakuan, pada perlakuan ransum konvensional mungkonsumsi ransum lebih tinggi disbanding dengan ransum buatan (Tabel 5.). Konversi pakan yang baik pada perlakuan ransum buatan dinilai dengan konsumsi ransum yang sedikit tetapi menghasilkan pertambahan berat badan yang tinggi dibandingkan dengan ransum konvensional.

Hasil analisis (uji-t) menunjukan bahwa perbedaan angka konversi pakan antara kedua perlakuan tidak signifikan. Perhitungan uji t (t-test) adalah -50,90 dari 2,101 ( $\left.\mathrm{t}_{\text {tabel }}\right)$. Hal ini kemungkinan terjadi karena pemberian pakan selama penelitian yang tidak efisien sehingga terjadi peningkatan pemberian pakan pada kedua perlakuan ini, namun masih terlihat bahwa sekalipun jumlah ransum konvensional yang dikonsumsi broiler lebih tinggi namun pertambahan berat badan tidak signifikan sehingga ransum yang lebih baik bagi broiler adalah ransum buatan yang dioleh dari bahan pakan lokal, Karena dengan mengkonsumsi ransum lebih sedikit namun menghasilkan berat badan yang lebih dibandingkan dengan ransum konvensional.

Pengaruh kekurangan energi pada performance sangat besar. Pengaruh terbesar pada broiler adalah memperburuk FCR (feed converse ratio). Pada saat energi per Kg pakan kurang dari kebutuhan, maka ayam akan makan lebih banyak untuk menjaga kebutuhan energinya. Walaupun ayam makan lebih banyak untuk pertambahan berat badanya tidak ikut meningkat dan ini membuat pemenuhan kebutuhan energi menjadi mahal serta mengurangi value dari energi itu sendiri (Sukarman, 2009).

\section{Simpulan}

Berdasarkan hasil penelitian dapat disimpulkan bahwa:

a. Ransum yang dibuat sendiri dengan memamfaatkan bahan pakan lokal seperti tepung sagu, tepung ikan, dedak padi, bungkil kedelai, tepung daun papaya, minyak kelapa, molasses, dan probiotik (Starbio) lebih baik dibandingkan ransum konvensional karena sekalipun pakan yang dikonsumsi lebih rendah namun menghasilkan pertambahan berat badan yang lebih baik dibanding dengan broiler yang mengkonsumsi ransum konvensional.

b. Broiler yang mengkonsumsi ransum buatan lebih efisien dalam penggunaan ransum dan biaya pakan ditandai dengan angka konversi ransum yang lebih baik dibandingkan dengan ransum konvensional.

\section{Pustaka}

Anggorodi R. 1980. Ilmu Makanan Ternak Umum. PT. Gramedia Pustaka Utama. Jakarta

Anonimous. 2008. Kemajuan Mutakhir dalam Ilmu Makanan Ternak Unggas. Universitas Indonesia Press. Jakarta.

Murtidjo B. A. 1991. Pedoman Beternak Ayam Broiler. Kanisius. Yogyakarta.

National Research Council (NRC). 1994. Nutrient Requirement of Poultry. National Academy Press, Washington, D.C.

Rasyaf M. 2004. Beternak Ayam Kampung. Penebar Swadaya, Jakarta

Sidadolog J. H. P. 1999. Menajemen Ternak Unggas. Hand Out. Fakultas Peternakan UGM. Yogyakarta

Sugiyono. 2006. Statistika Untuk Penelitian. Cetakan Ketujuh. CV. Alfabeta. Bandung.

Sukarman. 2009. Belajar Beternak Mandiri. [Internet]. [diunduh 15 Januari 2015].

Suprijatna E., Atmomarsono U. dan Kartasudjana R. 2005. Ilmu Dasar Ternak Unggas. Penebar Swadaya, Jakarta.

Soemantri dan Muhidin. 2006. Teknik Analisis dalam Penelitian Percobaan. Tarsito. Bandung.

Wiradisastra M. D. H. 1986. Evektivitas Keseimbangan Energi dan Asam Amino dan Efisiensi Absorpsi dalam Menentukan Persyaratan Kecepatan Tumbuh Ayam Broiler. Disertasi, Institut Pertanian Bogor, Bogor. 